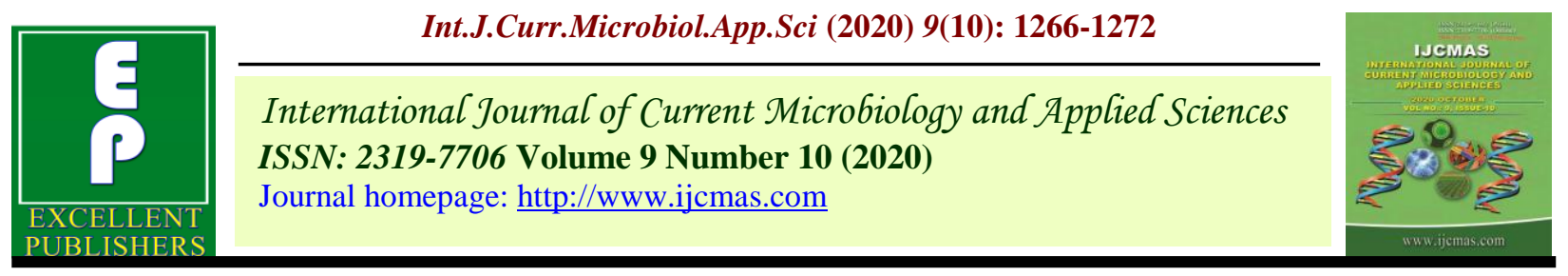

Original Research Article

https://doi.org/10.20546/ijcmas.2020.910.152

\title{
Correlation Studies and Path Coefficient Analysis in Chickpea (Cicer arietinum L.)
}

\author{
J. K. Dawane ${ }^{1^{*}}$, J. E. Jahagirdar ${ }^{2}$ and P. J. Shedge ${ }^{3}$ \\ Department of Agricultural Botany, College of Agriculture, \\ Badnapur, VNMKV Parbhani-431202 (India) \\ *Corresponding author
}

\begin{tabular}{|c|c|}
\hline & A B S T R A C T \\
\hline Keywords & \multirow{4}{*}{$\begin{array}{l}\text { The present investigation was carried out for, Correlation studies and Path } \\
\text { Coefficient Analysis in Chickpea (Cicer arietinum L.). Correlation studies } \\
\text { showed that the traits viz. harvest index, number of pods per plant, } 100 \text { seed } \\
\text { weight, number of seeds per pod and plant height exhibited positive and } \\
\text { highly significant genotypic correlation with seed yield. This indicates that } \\
\text { the simultaneous improvement of these characters through selection. Path } \\
\text { coefficient analysis indicated that the characters viz number of primary } \\
\text { branches per plant, plant height and days to } 50 \% \text { flowering exhibited } \\
\text { negative direct effect on seed yield per plant. Hence, the selection of } \\
\text { genotypes based on these characters as selection criterion would be helpful } \\
\text { in improving the seed yield potential of chickpea. }\end{array}$} \\
\hline $\begin{array}{l}\text { Chickpea, } \\
\text { Correlation, } \\
\text { Genotypic, } \\
\text { Phenotypic, } \\
\text { Path coefficient }\end{array}$ & \\
\hline Article Info & \\
\hline $\begin{array}{l}\text { Accepted: } \\
\text { 12 September } 2020 \\
\text { Available Online: } \\
10 \text { October } 2020\end{array}$ & \\
\hline
\end{tabular}

\section{Introduction}

Among the pulse, the chickpea is a important Rabi pulse crop of the region. Among all pulses chickpea contributes $36 \%$ area and $46 \%$ production in year 2017-18. During 2017-18 estimated area and production of chickpea in Maharashtra was 18.92 lakh ha and 17.61 lakh ton respectively. In Maharashtra, highest chickpea was grown on 19.29 lakh ha with the highest production of 19.41 lakh tones during 2016-17. The productivity is also highest during 2016-17 $(1006 \mathrm{~kg} / \mathrm{ha})$. In India percentage of area is increased upto $10.81 \%$ during year 2017-18 as compared to previous year while percentage of area decreased by $4.38 \%$ in Maharashtra. Maharashtra is having $14.69 \%$ contribution in the area with $13.74 \%$ production share in the nation (average of last ten years). Madhya Pradesh is having highest area of 35.90 lakh ha, production 45.95 lakh tons and productivity $1280 \mathrm{~kg} / \mathrm{ha}$ during the year 2017-18. During 2017-18, the area in Maharashtra was 20 lakh ha with production of 17.61 lakh tons and productivity is 881 $\mathrm{kg} / \mathrm{ha}$ [Anonymous, (2017)]. 
In year 2018-19, Maharashtra was having 13.14 lakh ha area with production of 9.87 lakh tons and productivity is $751 \mathrm{~kg} / \mathrm{ha}$ while Marathwada is having $4.78(36 \%)$ lakh ha area under chickpea, 2.99 (35\%) tons production and $630 \mathrm{~kg} / \mathrm{ha}$ productivity. In India chickpea is exported to countries like Pakistan, Arab EMTS, Algeria, Saudi Arab and Sri Lanka and however it is imported from Australia, Russia, Tanzania, USA and Canada (Annonymous, 2018-19).

In plant breeding, correlation coefficient analysis measures the mutual relationship between various variables and determines the component characters on which selection can be based for genetic improvement in yield. Correlation coefficient is a statistical measure which is used to find out the degree (strength) and direction of relationship between two or more variables.

The phenotypic and genotypic paths are commonly estimated to determine yield contributing characters which are useful for plant breeders and geneticists in selection of elite genotypes from diverse genetic population.

The association of one or more characters influenced by a large number of genes is elaborated statistically by correlation coefficients. Genotypic correlation coefficient provides a measure of genotypes conjugation between characters. The method of partitioning the correlation into direct and indirect effects by path coefficients analysis was suggested by Wright (1921). It provides useful information on the relative merits of the traits in the selection criteria. Breeder selects the parents on the basis of phenotypic divergence, but for effective breeding, the knowledge of genetic diversity amongst the parents with respect to the characters which are to be improved is essential.
In applied plant breeding, the correlation and path analysis provide information on genetic association of yield and different yield contributing characters, which in turn are useful in developing breeding strategies.

\section{Materials and Methods}

The present investigation on chickpea for correlation and path analysis was conducted at Agricultural Research Station, Badnapur, during Rabi season of 2017-18. The experimental materials used for study consisted of fourty three genotypes of chickpea, out of which 25 genotypes were obtained from International Crop Research Institute for Semi Arid Tropics, Hyderabad, 15 genotypes from the A.R.S. Badnapur and three standard checks.

Fourty genotypes of chickpea along with three standard checks viz. Akash (BDNG797), Digvijay, JAKI 9218 were evaluated in a randomized block design with two replications during Rabi season of 2017-18.

Each genotype was sown in two rows of $4 \mathrm{~m}$ length with spacing of $45 \mathrm{~cm}$ between rows and $10 \mathrm{~cm}$ within rows. The data were recorded on five randomly selected plants of each replication for all characters such as days to $50 \%$ of flowering, days to maturity, plant height $(\mathrm{cm})$, number of primary branches per plant, number of secondary branches per plant, number of pods per plant, number of seeds per pod, harvest index, 100 seed weight and seed yield.

The genotypic co-variance was calculated as per Johnson et al., (1955). To establish a cause and effect relationship the partitioning of genotypic and phenotypic correlation coefficient was done into direct and indirect effects by path analysis as suggested by Dewey and Lu (1959) and developed by Wright (1921). 


\section{Results and Discussion}

\section{Correlation coefficients}

The characters viz. harvest index, number of pods per plant, 100 seed weight, number of seeds per pod and plant height, days to maturity recorded highly positive significant correlation with seed yield. Seed yield per plant had positive significant correlation with harvest index $(\mathrm{p}=0.6868 ; \mathrm{g}=0.7787)$. Gohil et al., (2010) found that seed yield per plant exhibited significant and positive correlation with harvest index, number of pods per plant, 100 seed weight and number of seeds per pod at genotypic as well as phenotypic levels. Seed yield per plant had positive significant correlation with number of pods per plant $(\mathrm{p}=0.5504 ; \mathrm{g}=0.6338)$.

Earlier studies too have indicated such positive significant correlation for number of pods per plant by Guler et al., (2001). 100 seed weight ( $\mathrm{p}=0.3875 ; \mathrm{g}=0.4564)$, number of seeds per pod $(\mathrm{p}=0.3234 ; \mathrm{g}=0.4726)$ and plant height $\mathrm{cm}(\mathrm{p}=0.2467 ; \mathrm{g}=0.3429)$ also showed significant positive correlation with seed yield per plant. Akhtar et al., (2011) found that seed yield had positive and significant correlation with 100 seed weight, number of pods per plant and plant height. In other words, an increase in the magnitude of these characters would lead to an increase in the magnitude of grain yield (Fig. 1 and Table 1-3).

\section{Path analysis}

In path coefficient analysis the characters, number of pods per plant, harvest index, 100 seed weight, number of seeds per pod, plant height and number of secondary branches per plant had positive direct effect on seed yield in decreasing order of magnitude.

Among all the components number of pods per plant exhibited the highest direct effect
( $\mathrm{p}=0.4750)$ on seed yield followed by harvest index $(\mathrm{p}=0.3958), 100$ seed weight $(\mathrm{p}=3251)$, days to maturity $(\mathrm{p}=0.2735)$, number of seeds per pod $(p=0.2304)$, number of secondary branches per plant $(\mathrm{p}=0.0592)$, while number of primary branches per plant $(\mathrm{p}=-0.0259)$, plant height $(\mathrm{p}=-0.0361)$ and days to $50 \%$ flowering $(p=-0.2496)$, recorded negative direct effect at phenotypic level. Similar results were reported by Talebi et al., (2007) for number of pods per plant, number of seeds per pod and harvest index.

At genotypic level pods per plant exhibited the highest positive direct effect $(\mathrm{g}=0.5912)$ on seed yield followed by number of seeds per pod $(\mathrm{g}=0.5861), 100$ seed weight ( $\mathrm{g}=0.5623)$, days to maturity $(\mathrm{g}=0.3536)$, harvest index $(\mathrm{g}=0.2746)$, number of secondary branches per plant $(\mathrm{g}=0.2212)$. Parhe et al., (2014) recorded 100 seed weight, number of pods per plant and number of secondary branches per plant, plant had positive direct effect on seed yield and negative direct effect by number of primary branches per plant $(\mathrm{g}=-0.0532)$, plant height $(\mathrm{g}=-0.1552)$ and days to $50 \%$ flowering $(\mathrm{g}=-$ $0.1642)$.

Gaikwad and Monpara (2011) reported highest positive direct effect of number of pods per plant and 100 seed weight on grain yield. These findings revealed that these were major yield contributing traits in chickpea. Path coefficient analysis indicated that the characters viz., number of primary branches per plant, plant height and days to $50 \%$ flowering exhibited negative direct effect on seed yield per plant. But these characters had positive indirect effect via. another character on seed yield. Hence, the selection of genotypes based on these characters as selection criterion would be helpful in improving the seed yield potential of chickpea. 


\section{Int.J.Curr.Microbiol.App.Sci (2020) 9(10): 1266-1272}

Table.1 Estimation of phenotypic (above diagonal) correlation coefficients in chickpea

\begin{tabular}{|c|c|c|c|c|c|c|c|c|c|c|}
\hline Characters & $\begin{array}{c}\text { Days to } 50 \% \\
\text { flowering }\end{array}$ & $\begin{array}{l}\text { Days to } \\
\text { maturity }\end{array}$ & Plant height & $\begin{array}{c}\text { Number of } \\
\text { primary } \\
\text { branches / plant }\end{array}$ & $\begin{array}{c}\text { Number of } \\
\text { secondary } \\
\text { branches / plant }\end{array}$ & $\begin{array}{l}\text { Number of } \\
\text { pods / plant }\end{array}$ & $\begin{array}{l}\text { Number of seeds / } \\
\text { pod }\end{array}$ & $\begin{array}{c}100 \text { seed } \\
\text { weight }\end{array}$ & Harvest Index & $\begin{array}{c}\text { Seed } \\
\text { yield /plant }\end{array}$ \\
\hline & 1 & 2 & 3 & 4 & 5 & 6 & 7 & 8 & 9 & 10 \\
\hline Days to maturity & $0.9061 * *$ & 1.000 & $-0.3930 * *$ & $0.2989 * *$ & $0.3471 * *$ & 0.0169 & $-0.2859 * *$ & $-0.2684 *$ & -0.1336 & -0.1236 \\
\hline $\begin{array}{l}\text { Number of primary } \\
\text { branches per plant }\end{array}$ & $0.2971 * *$ & $0.2989 * *$ & -0.1911 & 1.000 & $0.4786 * *$ & 0.0570 & -0.1174 & $-0.2560 *$ & -0.1261 & -0.1161 \\
\hline $\begin{array}{l}\text { Number of secondary } \\
\text { branches per plant }\end{array}$ & $0.3220 * *$ & $0.3471 * *$ & $-0.2247 *$ & $0.4786 * *$ & 1.000 & $0.2916 * *$ & $-0.2623 *$ & $-0.2905 * *$ & -0.0701 & 0.0254 \\
\hline $\begin{array}{l}\text { Number of pods per } \\
\text { plant }\end{array}$ & -0.0347 & 0.0169 & 0.1681 & 0.0570 & $0.2916 * *$ & 1.000 & -0.0151 & -0.1715 & $0.2821 * *$ & $0.5504 * *$ \\
\hline 100 seed weight & $-0.3465 * *$ & $-0.2684 *$ & $0.2300 *$ & $-0.2560 *$ & $-0.2905 * *$ & -0.1715 & 0.1121 & 1.000 & $0.3129 * *$ & $0.3875 * *$ \\
\hline Harvest index & -0.2082 & -0.1336 & $0.2208 *$ & -0.1261 & -0.0701 & $0.2821 * *$ & 0.2115 & $0.3129 * *$ & 1.000 & $0.6868 * *$ \\
\hline Seed yield per plant & $-0.2527 *$ & -0.1236 & $0.2467 *$ & -0.1161 & 0.0254 & $0.5504 * *$ & $0.3234 * *$ & $0.3875 * *$ & $0.6868 * *$ & 1.000 \\
\hline
\end{tabular}

* Significant at $5 \%$ level of probability or level of significance,

$* *$ Significant at $1 \%$ level of probability or level of significance 
Table.2 Direct and indirect effect of yield and its component characters on grain yield at phenotypic level

\begin{tabular}{|c|c|c|c|c|c|c|c|c|c|c|}
\hline Characters & $\begin{array}{l}\text { Days to } 50 \\
\% \text { flowering }\end{array}$ & $\begin{array}{l}\text { Days to } \\
\text { maturity }\end{array}$ & $\begin{array}{l}\text { Plant } \\
\text { height }\end{array}$ & $\begin{array}{l}\text { Number } \\
\text { of primary } \\
\text { branches } \\
\text { per plant }\end{array}$ & $\begin{array}{c}\text { Number of } \\
\text { secondary } \\
\text { branches } \\
\text { per plant }\end{array}$ & $\begin{array}{l}\text { Number } \\
\text { of pods } \\
\text { per plant }\end{array}$ & $\begin{array}{l}\text { Number } \\
\text { of seeds } \\
\text { per pod }\end{array}$ & $\begin{array}{c}100 \\
\text { seed } \\
\text { weight }\end{array}$ & $\begin{array}{l}\text { Harvest } \\
\text { index }\end{array}$ & $\begin{array}{c}\text { Total } \\
\text { phenotypic } \\
\text { correlation } \\
\text { with seed } \\
\text { yield / plant }\end{array}$ \\
\hline $\begin{array}{l}\text { Days to } 50 \% \\
\text { flowering }\end{array}$ & $\underline{-0.2496}$ & -0.2261 & 0.1280 & -0.0741 & -0.0803 & 0.0086 & 0.0751 & 0.0865 & 0.0520 & -0.2527 \\
\hline Days to maturity & 0.2478 & $\underline{0.2735}$ & -0.1075 & 0.0817 & 0.0949 & 0.0046 & -0.0782 & -0.0734 & -0.0365 & -0.1236 \\
\hline Plant height & 0.0185 & 0.0142 & -0.0361 & 0.0069 & 0.0081 & -0.0061 & -0.0045 & -0.0083 & -0.0080 & 0.2467 \\
\hline $\begin{array}{l}\text { No. of primary } \\
\text { branches per plant }\end{array}$ & -0.0077 & -0.0077 & 0.0049 & $\underline{-0.0259}$ & -0.0124 & -0.0015 & 0.0030 & 0.0066 & 0.0033 & -0.1161 \\
\hline $\begin{array}{l}\text { No. of secondary } \\
\text { branches per plant }\end{array}$ & 0.0191 & 0.0206 & -0.0133 & 0.0283 & $\underline{0.0592}$ & 0.0173 & -0.0155 & -0.0172 & -0.0042 & 0.0254 \\
\hline $\begin{array}{l}\text { Number of pods per } \\
\text { plant }\end{array}$ & -0.0165 & 0.0080 & 0.0798 & 0.0271 & 0.1385 & $\underline{0.4750}$ & -0.0072 & -0.0814 & 0.1340 & 0.5504 \\
\hline $\begin{array}{l}\text { Number of seeds per } \\
\text { pod }\end{array}$ & -0.0693 & -0.0659 & 0.0287 & -0.0270 & -0.0604 & -0.0035 & $\underline{0.2304}$ & 0.0258 & 0.0487 & 0.3234 \\
\hline 100 seed weight & -0.1126 & -0.0873 & 0.0748 & -0.0832 & -0.0944 & -0.0557 & 0.0364 & $\underline{0.3251}$ & 0.1017 & 0.3875 \\
\hline Harvest index & -0.0824 & -0.0529 & 0.0874 & -0.0499 & -0.0277 & 0.1116 & 0.0837 & 0.1239 & $\underline{0.3958}$ & 0.6868 \\
\hline
\end{tabular}

Residual effect $=0.4913$, Underlined figures indicate direct effect.

$*$, ** indicates significant at 5 and $1 \%$ level of significant respective 
Table.3 Direct and indirect effect of yield and its component characters on grain yield at genotypic level

\begin{tabular}{|c|c|c|c|c|c|c|c|c|c|c|}
\hline Characters & $\begin{array}{c}\text { Days to } \\
50 \% \\
\text { flowering }\end{array}$ & $\begin{array}{l}\text { Days to } \\
\text { maturity }\end{array}$ & $\begin{array}{l}\text { Plant } \\
\text { height }\end{array}$ & $\begin{array}{l}\text { Number } \\
\text { of } \\
\text { primary } \\
\text { branches } \\
\text { per plant }\end{array}$ & $\begin{array}{c}\text { Number of } \\
\text { secondary } \\
\text { branches } \\
\text { per plant }\end{array}$ & $\begin{array}{l}\text { Number } \\
\text { of pods } \\
\text { per plant }\end{array}$ & $\begin{array}{l}\text { Number } \\
\text { of seeds } \\
\text { per pod }\end{array}$ & $\begin{array}{c}100 \\
\text { seed } \\
\text { weight }\end{array}$ & $\begin{array}{c}\text { Harvest } \\
\text { index }\end{array}$ & $\begin{array}{c}\text { Total } \\
\text { genotypic } \\
\text { correlation } \\
\text { with seed } \\
\text { yield / plant }\end{array}$ \\
\hline $\begin{array}{l}\text { Days to } 50 \% \\
\text { flowering }\end{array}$ & -0.1642 & -0.1524 & 0.1072 & -0.0565 & -0.0586 & 0.0068 & 0.0790 & 0.0671 & 0.0351 & -0.2691 \\
\hline Days to maturity & 0.3281 & $\underline{0.3536}$ & -0.1789 & 0.1088 & 0.1273 & 0.0098 & -0.1741 & -0.1257 & -0.0485 & -0.1667 \\
\hline Plant height & 0.1013 & 0.0785 & $\underline{-0.1552}$ & 0.0642 & 0.0437 & -0.0346 & -0.0680 & -0.0392 & -0.0448 & 0.3429 \\
\hline $\begin{array}{l}\text { No. of primary } \\
\text { branches per plant }\end{array}$ & -0.0183 & -0.0164 & 0.0220 & $\underline{-0.0532}$ & -0.0295 & -0.0056 & 0.0135 & 0.0240 & 0.0086 & -0.1984 \\
\hline $\begin{array}{l}\text { No. of secondary } \\
\text { branches per plant }\end{array}$ & 0.0789 & 0.0797 & -0.0220 & 0.1227 & $\underline{0.2212}$ & 0.0827 & -0.0984 & -0.0844 & -0.0194 & 0.0259 \\
\hline $\begin{array}{l}\text { Number of pods per } \\
\text { plant }\end{array}$ & -0.0245 & 0.0164 & -0.0623 & 0.0624 & 0.2211 & $\underline{\mathbf{0 . 5 9 1 2}}$ & -0.0099 & -0.1022 & 0.1950 & 0.6338 \\
\hline $\begin{array}{l}\text { Number of seeds per } \\
\text { pod }\end{array}$ & -0.2821 & -0.2886 & 0.1318 & -0.1490 & -0.2607 & -0.0098 & $\underline{0.5861}$ & 0.0601 & 0.1850 & 0.4726 \\
\hline 100 seed weight & -0.2297 & -0.1999 & 0.2569 & -0.2533 & -0.2145 & -0.0972 & 0.0577 & $\underline{0.5623}$ & 0.1932 & 0.4564 \\
\hline Harvest index & -0.0586 & -0.0377 & 0.0793 & -0.0445 & -0.0241 & 0.0905 & 0.0867 & 0.0944 & $\underline{0.2746}$ & 0.7787 \\
\hline
\end{tabular}


Fig.1 Diagram showing the genotypic correlation in yield and its component characters of Chickpea

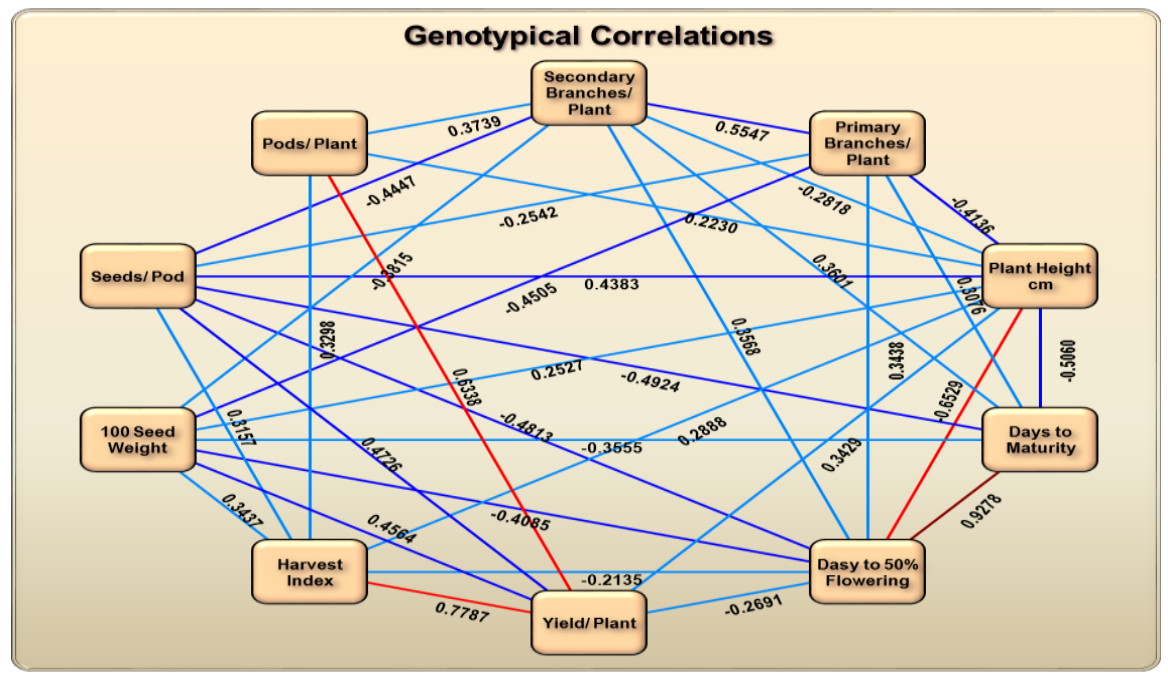

\section{References}

Akhtar L. H., Parvez Muhammad A. and Muhammad N. 2011. Genetic divergence and inter- relation studies in chickpea (Cicer arietinum L.). Pak. J. Agri. Sci. 48(1), 35-39.

Dewey, D.R. and Lu, K.H. 1959. A correlation and path coefficient analysis of component of Wheat grass seed production. Agron. J., 51: 515518.

Gaikwad, S.R. and Monpara, B.A. 2011. Genetic variation in F2 populations and their potential in the improvement of seed yield in chickpea (Cicer arietinum L.). J. Agric. Res. Technol. 36(3): 527530.

Gohil, D. P. and Patel, J.D. 2010. Character association and path analysis in chickpea (Cicer arietinum L.) under conserved soil moisture. Legume Res. 33(4): 283-286.

Guler, M., Adak, M.S. and Ulukah, H. 2001.
Determining relationship among yield and some yield components using path coefficient analysis in Chickpea. European J. Agron., 14(2): 161-166.

Johnson, H.W., Robinson, H.F. and Comstock, R.E. 1955. Genotypic and phenotypic correlation in soybean and their implications in selection. Agron. J., 47: 477-482.

Parhe S.D., Harer P.N. and Nagawade D.R. 2014. Investigation of genetic divergence in chickpea (Cicer arietinum L.) geotypes. The Bioscan an Int. Quarterly J. of Life Sci. 9(2):879882.

Talebi, R., Faydz, F. and Jelodar, A. 2007. Correlation and path coefficient analysis of yield and yield components of Chickpea under dryland condition in west of Iran. Asian J. of Plant Sci., 6 (7): 1151-1154.

Wright, S. 1921. Correlation and causation. $J$. Agric. Re., 20: 557-565.

\section{How to cite this article:}

Dawane, J. K., J. E. Jahagirdar and Shedge, P. J. 2020. Correlation Studies and Path Coefficient Analysis in Chickpea (Cicer arietinum L.). Int.J.Curr.Microbiol.App.Sci. 9(10): 1266-1272. doi: https://doi.org/10.20546/ijcmas.2020.910.152 